\title{
Oxidative stress in lymphoid tissues and complement activation in alcoholic mother rats and their newborns
}

\author{
Erdal İnce ${ }^{1}$, Fatma Curabeyoğlu ${ }^{2}$ and Sibel $\mathrm{Akyol}^{3}$ \\ ${ }^{1}$ Department of Medical Science Biology, Cerrahpasa Medical Faculty, Istanbul University - Cerrahpasa, Fatih/Istanbul, \\ Turkey \\ ${ }^{2}$ Vocational School of Health Care, Medical Laboratory, Istanbul Yeni Yuzyil University, Topkapi/Istanbul, Turkey \\ ${ }^{3}$ Department of Physiology, Cerrahpasa Medical Faculty, Istanbul University - Cerrahpasa, Fatih/Istanbul, Turkey
}

\begin{abstract}
Pregnant Wistar rats were exposed to ethanol under chronic conditions using the gavage method to assess the complement activation and effects of oxidative stress on fetus lymphoid organs and liver. The effects were monitored on both the 10th (G10) and the 30th (G30) day of the offspring of alcoholic mother rats. Maternal ethanol caused a significant decrease in the glutathione level, whereas malondialdehyde and carbonyl levels increased in the liver and lymphoid tissues. $\mathrm{Na}^{+}, \mathrm{K}^{+}$-ATPase, glutathione peroxidase, glutathione reductase, superoxide dismutase, and catalase activities in these organs also decreased. Furthermore, complement C 3 and C5 activities of G10 and G30 groups were significantly higher compared with those of the control group. In conclusion, the results demonstrated that alcohol was capable of triggering damage to the membranes of the liver and lymphoid tissues of G10 and G30 groups, and C 3 and C5 contributed to the development of alcohol-induced fetal tissue injury.
\end{abstract}

Key words: Maternal ethanol - Lymphoid tissue injury - Complement activation — Oxidative stress

Abbreviations: AT, acetaldehyde; CAT, catalase; CL, chemiluminescence assay; FASD, fetal alcohol spectrum disorder; GP, glutathione peroxidase; GR, glutathione reductase; GSH, reduced glutathione; GSSG, oxidized glutathione; LP, lipid peroxidation; MDA, malondialdehyde; PO, protein oxidation; ROS, reactive oxygen species; SOD, superoxide dismutase.

\section{Introduction}

Maternal alcohol consumption during pregnancy can have toxic effects on the mother and the developing fetus depending on the acute or chronic use and the dose. This is because alcohol rapidly diffuses through the placental barrier, and the alcohol content in the fetal blood emerges as equal to that in the maternal blood within minutes of the onset of a drinking episode. Evidence suggests that in utero embryonic and fetal exposure to ethanol leads to morphological and behavioral or neuro developmental anomalies (Paintner et al. 2012; Guevara et al. 2018). At present, this spectrum is collectively

Correspondence to: Sibel Akyol, Department of Physiology, Cerrahpasa Medical Faculty, Istanbul University - Cerrahpasa, Fatih/ Istanbul, Turkey

E-mail: 1923nurak@gmail.com termed fetal alcohol spectrum disorder (FASD). FASD includes alcohol-related birth defects, alcohol-related neurological disorders, and fetal alcohol syndrome (FAS) (May et al. 2009). FAS causes mental retardation and growth deficits together with facial anomalies in newborns of chronic alcohol-consuming mothers (Miller et al. 2013). Several studies have demonstrated that one of the mechanisms implicated in ethanol teratogenicity is oxidative stress (Mancinelli et al. 2014). When ethanol is consumed, it is readily absorbed from the gastrointestinal tract into the blood. Most of the ingested alcohol is metabolized by adult and fetal alcohol dehydrogenase, which converts ethanol into its corresponding aldehydes using nicotinamide adenin dinucleotide $\left(\mathrm{NAD}^{+}\right)$as a cofactor (Crabb et al 2004). Acetaldehyde (AT), the product of ethanol oxidation, is a highly unstable and reactive compound that has a high affinity for sulfhydryl groups within cells or tissues, and is also capable of reacting covalently with 
nucleophiles, including nucleic acids, lipids, carbohydrates, amino acids, peptides, and proteins (Deitrich et al. 2006). Ethanol-induced protein adducts have been postulated to alter cellular function by direct toxicity as well as producing immune-mediated tissue damage. Excess production of AT promotes lipid peroxidation, protein oxidation, mobilization of ferritin irons and also reactive oxygen species (ROS) production. As a result, membrane and enzyme function may be disrupted via overproduction of ROS and, therefore, alter tissue glutathione (GSH) and antioxidant enzymes such as glutathione peroxidase (GP), glutathione reductase (GR), superoxide dismutase (SOD), and catalase (CAT) (Cohen et al. 2003; Brocardo et al. 2011). Recent studies have shown that maternal ethanol induces oxidative stress; increases lp in fetal liver, brain, kidneys, and testes; and causes oxidative DNA damage in mouse embryos (Dong et al. 2010; Ceni et al. 2014), leading to severe birth defects (Greenberg 2003). Lymphoid tissues are responsible for regulating immune responses and function. Also, the lymphoid tissue cells are sensitive to changes in the antioxidant status because they carry out important functions by generating a high number of oxygen free radicals (Ozerkan et al. 2014). Moreover, the cells of the immune system have a high percentage of polyunsaturated fatty acids in their plasma membranes, and therefore, it is not surprising that these cells usually contain a higher concentration of antioxidants compared with other cells (Hatam and Kayden 1979). Research using animal models has shown that prenatal ethanol exposure negatively affects lymphoid tissue development, immune cell function, humoral immunity, and cytokine secretion (Terasaki and Schwarz 2016). Interestingly, no study concerning maternal alcohol administration in lymphoid tissue on FASD exists.

Another key hallmark is inflammation; toxic compounds produced in excess and antioxidant deficiencies or oxidative stress might be pathogenic factors in the alcoholic injury of lymphoid tissues in chronic alcoholism. The complement cascade has three different pathways: classical, lectin, or alternative. Complement activation has been shown to be associated with oxidative stress in numerous studies. ROS (such as $\mathrm{H}_{2} \mathrm{O}_{2}$ ) has been reported to be activated via the nonenzymatic pathway directly, and the inhibition of ROS formation decreases complement activation and deposition. The initiators of the three pathways are different, but all three ultimately lead to the activation of complement component 3 (C3). Complement activation leads to increased expression of inflammatory cytokines and chemokines and is involved in host defense as well as wound healing and response to tissue injury (Collard et al. 1998; Cohen et al. 2011). Increasing evidence suggests that alcohol-induced liver injury may be associated with increased oxidative stress and complement activation. The $\mathrm{Clq}$ can independently interact with a multiplicity of biological structures, including pathogenassociated and cell-associated molecules (danger-associated oligosaccharide structures or lipids; Ghebrehiwet et al. 2017), occurring via the opsonization of immune complexes and cellular debris by the $\mathrm{C} 1 /$ classical pathway and production of C3 fragments (Mevorach et al. 1998). Recently, C1q and C3 have been shown to contribute to the pathogenesis of ethanol-induced liver injury (Shen et al. 2014). Currently available data suggest that $\mathrm{C} 3$ or $\mathrm{C} 5$ protects from chronic ethanol-induced liver injury in C3- and C5-deficient mice (Pritchard et al. 2007). Furthermore, the inhibition of the complement cascade has been reported to produce a better outcome in the heart, liver, and brain after ischemic damage (Mocco et al. 2006; Ducruet et al. 2009). Therefore, together, the $\mathrm{C} 1 \mathrm{q}$ family of proteins is able to not only modulate the inflammatory and adaptive responses but also enhance the clearance of apoptotic cells by macrophages. Although increasing evidence indicates that complement is a convincing contributor to the pathophysiology of ethanol-induced tissue injury (especially in the liver and brain), the mechanisms by which ethanol activates the complement in lymphoid tissues have not been investigated. On the basis of the experimental studies, using biochemical approaches, the present study aimed to investigate the alcohol-induced oxidative stress and associated C3 and C5 activities on the lymphoid tissues in excess in rats fed chronically with alcohol and their newborn on the 10 th and 30 th days.

\section{Materials and Methods}

\section{Experimental procedure}

All experimental protocols were approved by the Cerrahpasa Medical Faculty Animal Care and Use Committee and we followed the National Institutes of Health (Washington, DC) Guide for the Care and Use of Laboratory Animals. Ten adult male and 30 adult female Wistar rats (aged 6-7 months; Cerrahpasa Medical Faculty Experimental Research Centre, Istanbul/Turkey) weighing 180-200 g were used for this experimental study. For mating, a male rat was randomly picked up and placed into a female's cage. They were placed in a secluded, temperature- and humidity-controlled room $\left(22 \pm 3^{\circ} \mathrm{C}\right.$ and $60 \pm 5 \%$, respectively) in which a $12 / 12-\mathrm{h}$ light-dark cycle was maintained.

Pregnant rats were obtained by mating overnight with a sexually experienced male. Pregnancy was confirmed by vaginal smear and embryonic day zero was determined by the presence of sperm in a vaginal smear (Marcondes et al. 2002).

Pregnant rats were assigned into three groups: the control group, which received isotonic sodium chloride (isc) intraperitoneally (i.p.) during pregnancy from 1 to 21 days gestation and during lactation until postnatal day 10 (C10) and 30 (C30), alcoholic mother's 10-day-old newborn (G10) 
and alcoholic mother's 30-day-old newborn (G30). When pregnancy was established, $40 \% \mathrm{v} / \mathrm{v}$ ethanol ( $4 \mathrm{~g} / \mathrm{kg}$ ) was administered intragastrically. The treatment was carried out during pregnancy and during lactation until postnatal day 10 and 30 .

All animals were also fed a standard laboratory diet (carbohydrate, $50 \%$; lipid, $22 \%$; protein, $25 \%$ ).

On days 15,18 , and 20 of pregnancy, a $20-\mu$ blood sample was taken from the tails of the rats every morning 6 and $22 \mathrm{~h}$ after the administration of fresh diets. Plasma was immediately separated following centrifugation and quantified at $340 \mathrm{~nm}$ to determine the blood alcohol concentration (BAC; NAD-ADHReagent Multiple Test Vial; Sigma-Aldrich, MO, USA) using a Shimadzu UV-1201 spectrophotometer (Shimadzu Corporation, Kyoto, Japan). For each group, on days E15, E18, and E20, a total of six values were obtained as a result of two applications per day (Lundquist 1959). The highest values of these were defined as the peak BAC for each group.

\section{Biochemical analyses}

The rats were fasted overnight. The next morning, under light ether anesthesia (inhaled $4000 \mathrm{ppm} / \mathrm{h}$ ), the heart was punctured using an injector, and the blood was collected into biochemical test tubes. Blood samples were also collected from the heart of the offspring on the day lactation ceased (days 15 and 30). Blood test tubes were centrifuged at $2000 \times g$ for $10 \mathrm{~min}$ at room temperature, and the serum was separated. After removing the blood samples, the rats were killed by decapitation, and lymphoid (thymus, spleen, and lymph nodes) and nonlymphoid (liver) tissues were surgically removed. Tissues used for biochemical studies were frozen in liquid nitrogen and kept at $-80^{\circ} \mathrm{C}$ until further use. Tissue samples were excised and weighed, and a part of it was minced and homogenized well in liquid nitrogen. Then, the homogenate was sonicated for $60 \mathrm{~s}$ at $220 \mathrm{~V}$ (Sonic Dismembrator, Model 300 (Fisher, Germany) in each cold assay buffer. All chemicals used for the experiments were of analytical grade and purchased from Merck (Darmstrat Germany) and Sigma-Aldrich (MO, USA)

\section{Lipid peroxidation measurement}

Tissue samples were estimated spectrophotometrically by the thiobarbituric acid-reactive substance method with Singh et al (2000) and expressed in terms of malondialdehyde (MDA) formed per mg protein (nmol MDA/mg protein). Briefly, 0.2 $\mathrm{ml}$ of tissue homogenate supernatant was mixed with $0.8 \mathrm{ml}$ of $0.15 \mathrm{M}$ Tris $\mathrm{KCl}$ buffer to which $0.25 \mathrm{ml}$ of $30 \%$ trichloroacetic acid (TCA) was added and then $0.25 \mathrm{ml}$ of $52 \mathrm{mM}$ thiobarbutiric acid (TBA) was added and placed in a water bath for $1 \mathrm{~h}$ at $90^{\circ} \mathrm{C}$, cooled in ice and centrifuged at room temperature for $15 \mathrm{~min}$ at $3200 \mathrm{rpm}$. The absorbance of the clear supernatant and standards $(0.01-10 \mu \mathrm{M})$ were measured against the reference blank of distilled water at $532 \mathrm{~nm}$ spectrophotometer (UV-160A Shimadzu). Protein was determined according to the method of Lowry et al (1951).

\section{Protein oxidation measurement}

Measurements of protein (carbonyl) oxidation in stomach samples and serum were made by the method of Evanset al (1999) with slight modifications. The homogenized lymphoid tissues were transferred to an Eppendorf tube, and then streptomycin sulfate solution $(10 \% \mathrm{w} / \mathrm{v})$ was added to a final concentration of $1 \%$ to precipitate any extracted DNA which could react with 2,4 dinitrophenylhdrazine (DNPH) and contribute to the carbonyl level. The mixture was mixed and left to stand for $10 \mathrm{~min}$ at room temperature, after which it was centrifuged at $3000 \times g$ for $10 \mathrm{~min}$ at room temperature. The supernatant was removed in $0.3 \mathrm{ml}$ aliquots into two tubes. DNPH $(1.2 \mathrm{ml}, 10 \mathrm{mM}$ in $2 \mathrm{M} \mathrm{HCl})$ was added to one tube and $1.2 \mathrm{ml}$ of $2 \mathrm{M} \mathrm{HCl}$ to the other tube. The tubes were then incubated for $1 \mathrm{~h}$ on a shaker at room temperature and then the protein was precipitated by adding $0.3 \mathrm{ml}$ of $20 \%(\mathrm{w} / \mathrm{v})$ trichloroacetic acid to each tube and left for $10 \mathrm{~min}$. Protein was spun down at $5000 \times g$ for $5 \mathrm{~min}$, the supernatant was discarded and the pellet was washed with $1.25 \mathrm{ml}$ of an ethyl acetate: ethanol mixture $(1: 1, \mathrm{v} / \mathrm{v})$ to remove excess DNPH. This procedure was repeated three times. The final pellet was dissolved in $0.938 \mathrm{ml}$ of $6 \mathrm{M}$ guanidine hydrochloride and the absorbance of both solutions (DNPH and $\mathrm{HCl}$ ) measured at $370 \mathrm{~nm}$ from which the carbonyl content could be evaluated (carbonyl concentration in $\mathrm{nM}: \triangle A 370 \times 45.45$, where $\triangle A 370$ equals $A 370$ of $\mathrm{DNPH}$ solution - $A 370$ of $\mathrm{HCl}$ solution). The protein concentration was calculated from the $A 280$ of the $\mathrm{HCl}$ samples $(A 280 \times 1.8$ gives the protein concentration in $\mathrm{mg} / \mathrm{ml})$. Carbonyl concentration $(\mathrm{nmol} / \mathrm{mg}$ of protein $)=$ $\mathrm{nmol} / \mathrm{ml}$ of carbonyl groups/protein concentration in $\mathrm{mg} / \mathrm{ml}$.

\section{$\mathrm{Na}^{+}, \mathrm{K}^{+}$ATPase activity measurement}

It is based on the measurement of inorganic phosphate that is formed from $3 \mathrm{mM} \mathrm{Na}{ }_{2} \mathrm{ATP}$ added to the medium during the incubation period (Reading and Isbir 1980). The medium incubated in a $37^{\circ} \mathrm{C}$ water bath for $5 \mathrm{~min}$ with a mixture of $100 \mathrm{nM} \mathrm{Na} 2 \mathrm{Cl}, 5 \mathrm{mM} \mathrm{KCl}, 6 \mathrm{mM} \mathrm{MgCl} 2,0.1 \mathrm{mM}$ EDTA, $30 \mathrm{mM}$ Tris- $\mathrm{HCl}$ ( $\mathrm{pH}$ 7.4). Following the preincubation period, $\mathrm{Na}_{2} \mathrm{ATP}$, at final concentration of $3 \mathrm{mM}$, was added to each tube and incubated at $37^{\circ} \mathrm{C}$ for $30 \mathrm{~min}$ after the incubation, the tubes were placed in an ice bath and the reaction was stopped. Subsequently, the level of inorganic phosphate was determined in a spectrophotometer at an excitation wavelength of $690 \mathrm{~nm}$. The specific activity of the enzyme is expressed as nanomoles Pi per miligram of protein per hour. 


\section{Tissue chemiluminescence assay}

Measurements were made at room temperature using a junior LB 9509 luminometer (EG\&G Berthold, Germany). Speciments $(0.1 \mathrm{~g})$ were put into vials containing PBS and 4-(-2-hydroxyethyl) piperazine-1-ethanesulphonic acid acid (HEPES) buffer (0.5 M PBS containing $20 \mathrm{mM}$ HEPES, $\mathrm{pH}$ 7.2). ROS were quantited after the addition of either lucigenin or luminol for a final concentration of $0.2 \mathrm{mM}$. Luminol detected a group of reactive species, i.e. hydroxyl radical $\left(\mathrm{OH}^{\cdot}\right)$, hydrogen peroxide $\left(\mathrm{H}_{2} \mathrm{O}_{2}\right)$, while lucigenin is selective for super oxide radicals $\left(\mathrm{O}_{2}{ }^{-}\right)$(Davies et al. 1992). Counts were obtained at $1 \mathrm{~min}$ intervals and the results were given as the area under curve for a counting period of $5 \mathrm{~min}$. Counts were corrected for wet tissue weight and expressed as relative ligth units (rlu/mg tissue) (Haklar et al. 1998).

\section{Total GSH measurement}

GSH was measured by an adaptation of the method of Beutler et al (1963). For this, $0.2 \mathrm{ml}$ of homogenate was vortexed in $0.2 \mathrm{ml}$ of $0.5 \mathrm{M}$ perchloric acid to precipitate protein. After centrifugation, $300 \mu \mathrm{l}$ of the supernatant was added to 600 $\mu \mathrm{l} 0.3 \mathrm{M} \mathrm{Na}_{2} \mathrm{HPO}_{4}$ and $150 \mu \mathrm{l}$ Ellman's reagent prepared by

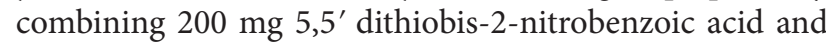
$5 \mathrm{~g}$ sodium citrate in $11 \mathrm{HPLC}$ grade water. After incubation at $37^{\circ} \mathrm{C}$ for $15 \mathrm{~min}$, the yellow colour formed was measured against a reagent blank at $412 \mathrm{~nm}$ in a spectrophotometer (UV-160A Shimadzu). A daily standard curve was prepared with glutathione $(1-100 \mu \mathrm{M})$.

\section{GP measurement}

GP activity was measured by the methods of Paglia and Valentine (1967). In this method, GP catalyzes the oxidation of glutathione in the presence of tert-butyl hydroperoxide. Oxidized glutathione is converted to the reduced form in the presence of glutathione reductase and NADPH, while NADPH is oxidized to NADP. The reduction in absorbance of NADPH at $340 \mathrm{~nm}$ is measured. The absorbance change per min and the molar extinction coefficient of NADPH are used to calculate GP activity. GP activity expressed as $\mu \mathrm{mol}$ $\mathrm{NADPH} / \mathrm{min} / \mathrm{g}$ tissue.

\section{GR measurement}

GR enzyme activity was analyzed according forth method of Beutler (1985). Fifty of NADPH (2 mM) in 10 mM Tris$\mathrm{HCl}$ buffer ( $\mathrm{pH} 7.0$ ) was added to a cuvette containing $50 \mu \mathrm{l}$ of GSSG (20 mM) in phosphate buffer (0.5 M, pH 7.0) and $850 \mu \mathrm{l}$ phosphate buffer and was then incubated at $37^{\circ} \mathrm{C}$ for $10 \mathrm{~min} .10 \mu \mathrm{l}$ homogenate was added to the NADPH-GSSG buffered solution and measured at $340 \mathrm{~nm}$ for $30 \mathrm{~min}$. GR activity expressed as $\mu \mathrm{mol} \mathrm{NADPH} / \mathrm{min} / \mathrm{g}$ tissue. The results were expressed in $\mathrm{nmol} / \mathrm{mg}$ protein.

\section{SOD measurement}

SOD activity was determined according to the method of Winterbourn et al. (1975). In this method, a xanthinexanthine oxidase complex produces superoxide radicals, which react with nitrobluetetrazolium (NBT) to form the farmasone compound. The SOD activity is measured at $560 \mathrm{~nm}$ by detecting the inhibition of this reaction. One unit of SOD activity is defined as the activity that causes $50 \%$ inhibition of NBTH 2 reduction rate. One unit of SOD expressed in $\mathrm{U} / \mathrm{mg}$ protein was designated as the amount of enzyme that inhibits the reduction of nitrobluetetrazolium reduction by $50 \%$.

\section{CAT measurement}

CAT activity was determined according to the method of Aebi (1985). $\mathrm{H}_{2} \mathrm{O}_{2}$ solution (10 mM), enzyme extract, and $50 \mathrm{mM}$ phosphate buffer ( $\mathrm{pH}$ 7.0) were pipetted into a cuvette. The reduction of $\mathrm{H}_{2} \mathrm{O}_{2}$ was followed at a wavelength of $240 \mathrm{~nm}$ for 4 min against a blank containing $50 \mathrm{mM}$ phosphate buffer and enzyme extract. The activity was expressed as $\mathrm{U} / \mathrm{mg}$ protein.

\section{Complement 3 (C3) and complament 5 (C5) measurement}

ELISA kit (C3, bio search cat no: MBS724829; C5, bio search cat. no: MBS721993 USA) was used to obtain, complement C3 and C5 assays.

\section{Statistical analysis}

SPSS software, version 15.0 for Windows (SPSS, Inc., Chicago, IL, USA) was used for the statistical analysis of biochemical data. In order to, assess differences between groups, one-way analysis of variance (ANOVA) and Turkey's multiple comparison test were used. Results were presented as mean $\pm \mathrm{SD}$ and $p<0.05$ was considered to indicate a statistically significant result.

\section{Results}

As shown in Figure 1A, chronic administration of ethanol in pregnant rats resulted in a massive increase in the MDA content in liver and lymphoid tissue of the G10 and G30 groups compared with the $\mathrm{C}$ group $(p<0.001)$. The levels of another oxidative marker protein oxidation in the liver and lymphoid tissues were significantly higher in the G10 and G30 groups than in the $\mathrm{C}$ group $(p<0.001$; Figure $1 \mathrm{~B}) . \mathrm{Na}^{+} /$ 
A

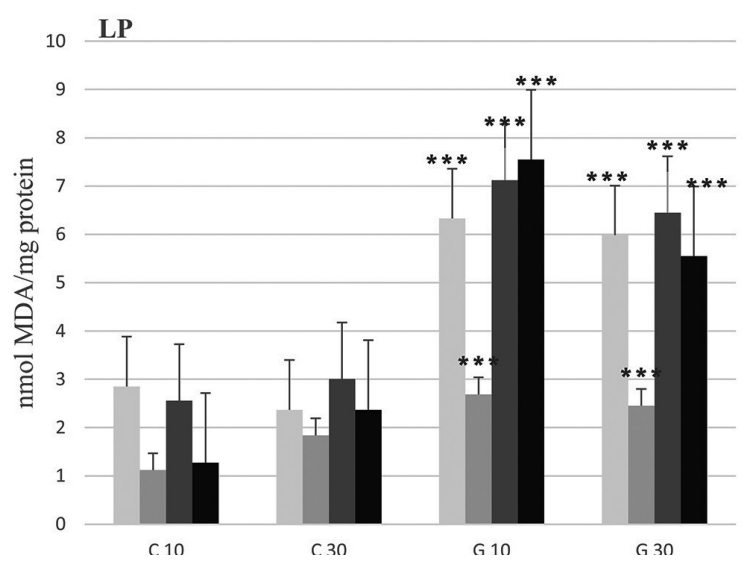

C

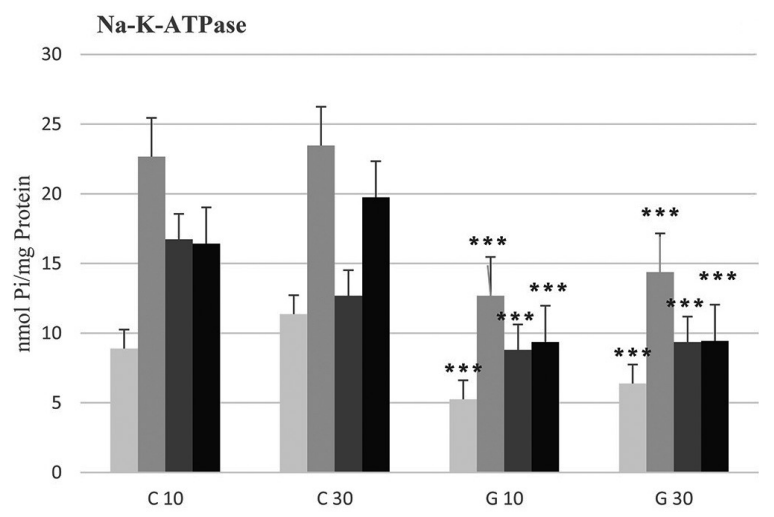

$\mathbf{E}$

GP

$$
25
$$

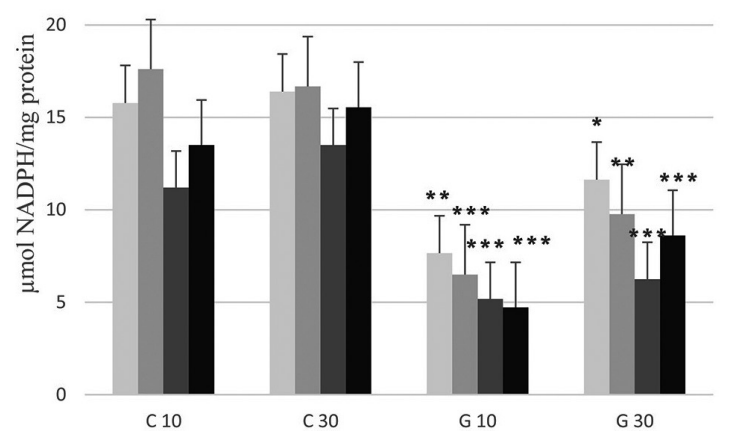

B

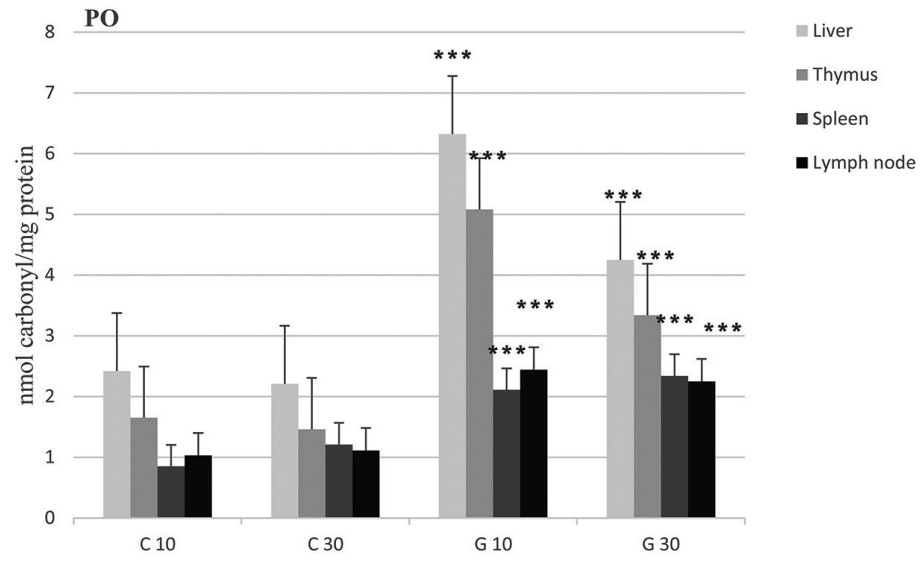

D

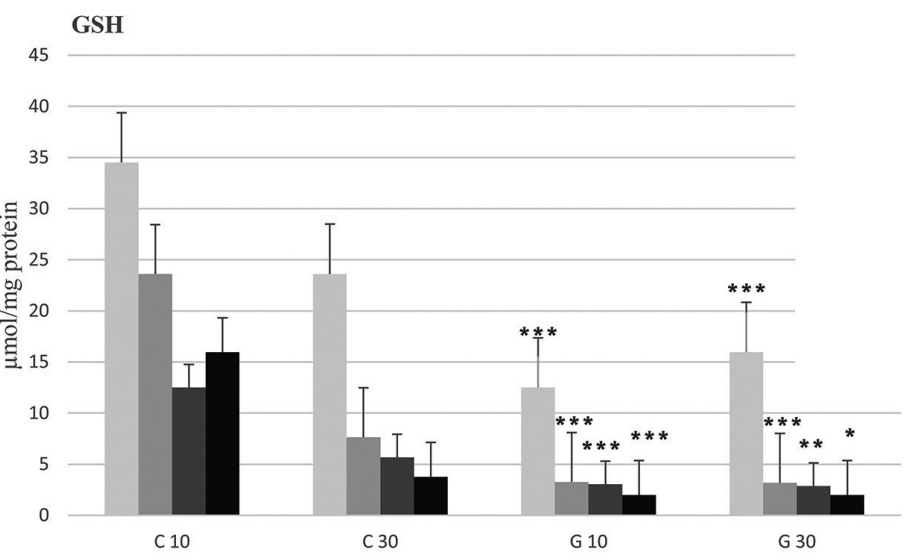

$\mathbf{F}$

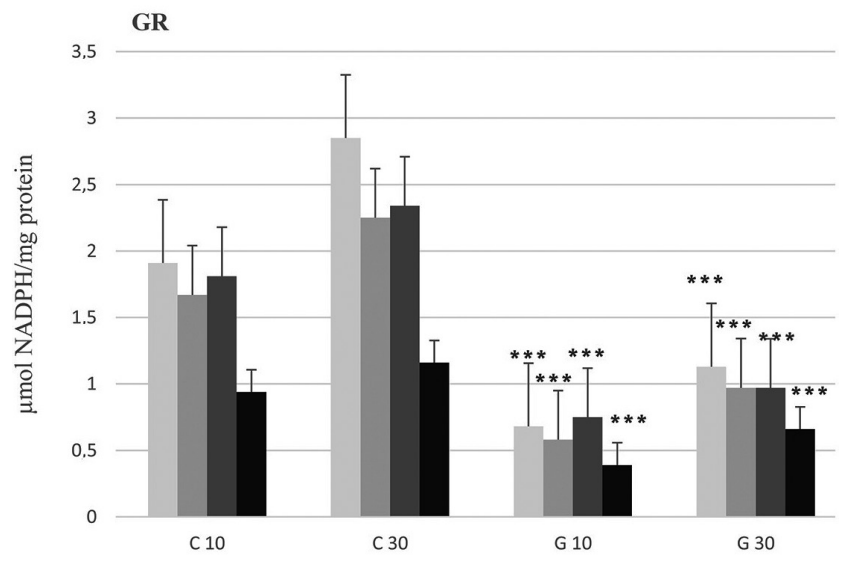

Figure 1. Effect of chronic alcohol consumption on lipid peroxidation (LP) levels (A), protein oxidation (PO) levels $(\mathbf{B}), \mathrm{Na}^{+} / \mathrm{K}^{+}-\mathrm{ATPase}$ activities (C), reduced glutathione (GSH, D), glutathione peroxidase (GP, E) and glutathione reductase (GSR, F) in liver and lymphoid tissues of 10 and 30 day old offsprings. ${ }^{* *} p<0.001 v s$. control group. For more details, see Materials and Methods. 
A

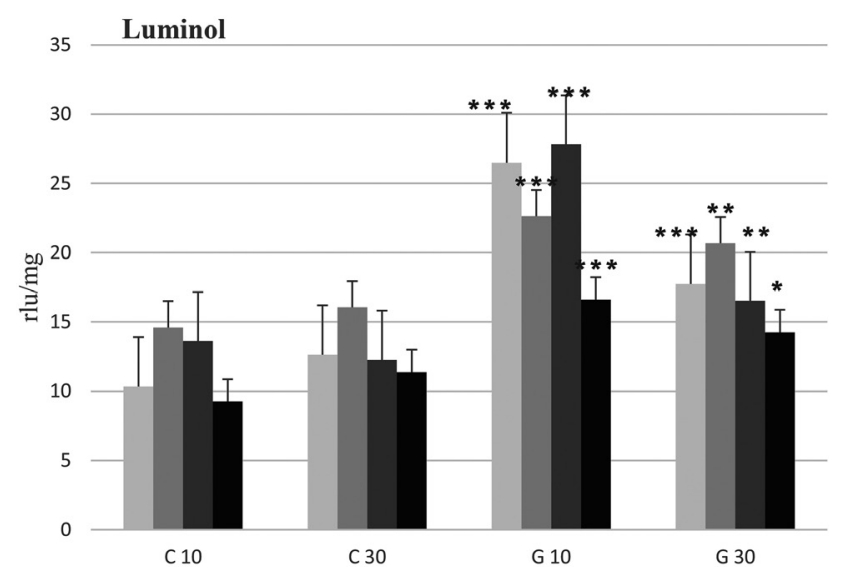

B

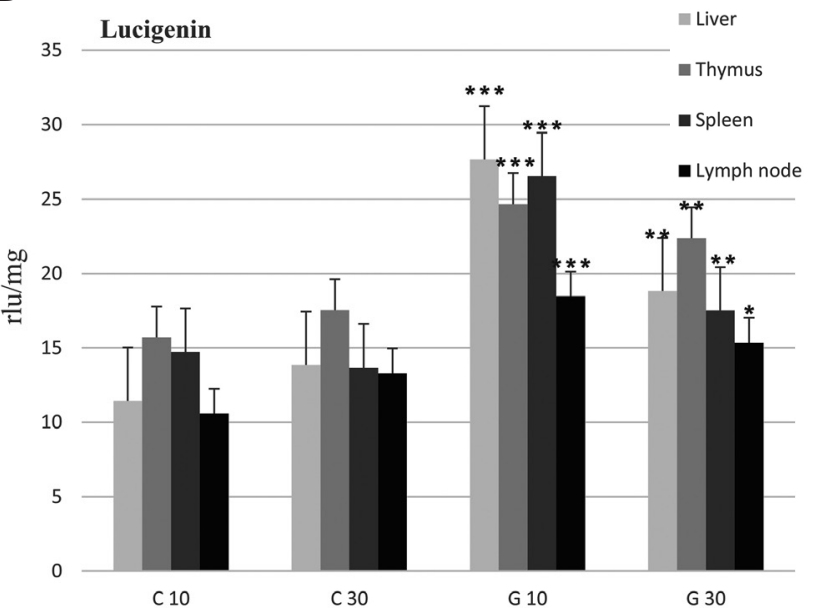

Figure 2. Effect of chronic alcohol consumption on luminol (A) and lucigenin (B) chemiluminescence in liver and lymphoid tissues of 10 and 30 day old offsprings. ${ }^{*} p<0.05,{ }^{* *} p<0.01,{ }^{* * *} p<0.001 v$ s, control group.

$\mathrm{K}^{+}$-ATPase activities significantly decreased in the $\mathrm{G} 10$ and G30 groups than in the $\mathrm{C}$ group $(p<0.001$; Figure $1 \mathrm{C})$. The chemiluminescence levels in the liver and lymphoid tissue samples detected using both luminol and lucigenin probes showed significant increases in the G10 and G30 groups than in the C group $(p<0.05-p<0.001$; Figures $2 \mathrm{~A}, \mathrm{~B})$. In accordance with this, ethanol caused a significant decrease in liver and lymphoid GSH levels in the G10 and G30 groups compared with the C group ( $p<0.05-\mathrm{p}<0.001$; Figure 1D). The enzymatic GP activities significantly decreased in the liver and lymphoid tissue of G10 and G30 groups compared with $\mathrm{C}$ group $(p<0.05-\mathrm{p}<0.001$; Figure $1 \mathrm{E})$. As shown in Figure 1F, the GR activity in the studied tissues of G30 and G10 markedly decreased significantly compared with the C group $(p<0.001)$. As shown in Figure 3A, the SOD activation significantly decreased in the liver and lymphoid tissue of G10 and G30 groups compared with the C group $(p<0.01, p<0.001)$. Similarly, CAT activation in the liver and lymphoid tissues significantly decreased compared with the C group ( $p<0.001$; Figure 3B). C3 and C5 activities were significantly higher in the G10 and G30 groups than in the C group $(p<0.01, p<0.001$; Figure 4$)$.
A

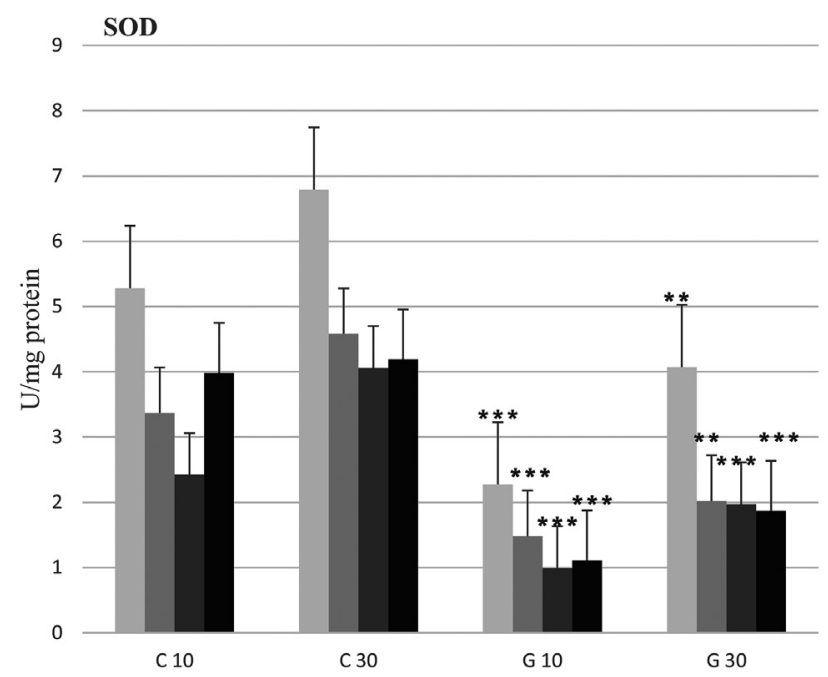

B

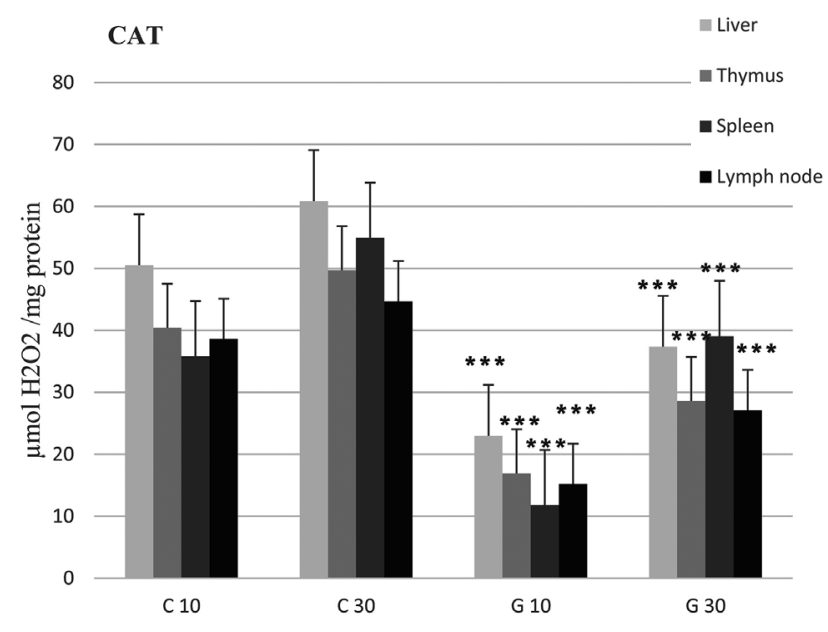

Figure 3. Effect of chronic alcohol consumption on super oxide dismutase (SOD, A) and catalase (CAT, B) activities in liver and lymphoid tissues of 10 and 30 day old offsprings. ${ }^{*} p<0.05,{ }^{* *} p<0.01,{ }^{* *} p<0.001 v s$, control group. 


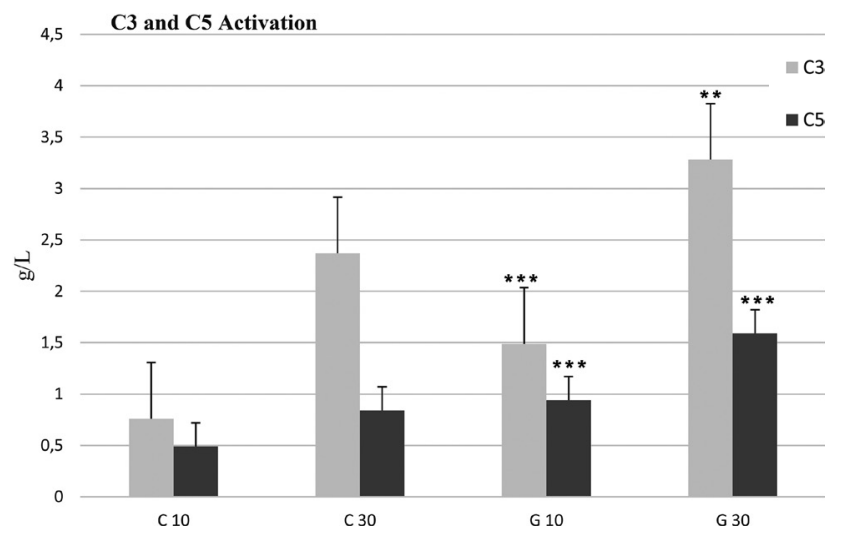

Figure 4. Effect of chronic alcohol consumption on complement C3 and C5 activities in 10 and 30 day old offsprings. ${ }^{* *} p<0.01$, ${ }^{* * *} p<0.001 v s$, control group.

\section{Discussion}

This novel study examined maternal alcohol administration in lymphoid tissue on FASD. The results of the present study demonstrated that maternal alcohol caused oxidative tissue damage in the liver and lymphoid tissues (thymus, spleen, and lymph nodes) of the newborn rats (10 and 30 days old), as assessed by increased MDA, protein oxidation, CL levels; concomitant reduction in GSH levels and $\mathrm{Na}^{+} / \mathrm{K}^{+}$ATPase, GP, GR, SOD and CAT activities. Furthermore, the alcohol-induced ROS evaluation in plasma C3 and C5 was increased. Both clinically and experimentally, chronic excessive alcohol consumption impaired the function of a wide range of cells and tissues (Molina et al. 2003), but the mechanism and the extent of damage on different cell and organ systems have not been explained well. As implied in many studies, a major indicator of the cellular and molecular mechanisms of alcohol-induced tissue injury is the formation of ROS and the metabolite AT generation of ethanol. As a result of the formation of protein adducts (producing immune-mediated tissue damage), the activities of mitochondria and restorative enzymes were disrupted. Furthermore, both human and animal experimental studies reported that AT caused a reduction in the number of GSH groups and hydrophobic regions on the cell membrane and mitochondrial membranes (Wu and Cederbaum 2003). In the present study, MDA, a marker of lipid peroxidation, increased in the liver and lymphoid tissues, indicating the presence of maternal alcohol - induced oxidative damage. In accordance with the present findings, previous fetotoxicity studies showed that lipid peroxidation increased in the liver and brain tissues (Shirpoor et al. 2008). Moreover, luminol and lucigenin enhanced CL data supported, that tissue injury induced by maternal alcohol involved the generation of toxic oxygen metabolites. Protein (carbonyl) oxidation and lipid peroxidation levels were widely used as biomarkers of tissue damage or oxidative stress (Augustyniak and Skrzydlewska 2010). As shown in Figure $1 B$, the protein oxidation levels significantly increased $(p<0.001)$ in G10 and G30 compared with the controls. Recent studies have shown that oxidized proteins are often functionally inactive, and their unfolding is associated with enhanced susceptibility to proteinases (Henderson et al. 1999). Sulfhydryl-containing proteins are considerable targets for free radicals and AT as well (Abraham et al. 2002). $\mathrm{Na}^{+} / \mathrm{K}^{+}$-ATPase is an enzyme located in the cell membrane responsible for the active transport of various ions, thus maintaining the ionic and osmotic balance of the cells. Membrane-bound enzymes, such as $\mathrm{Na}^{+}$/ $\mathrm{K}^{+}$-ATPase, require phospholipids for the maintenance of their activity and are susceptible to structural changes due to LP (Prabbu and Balasubramanian 2003). Therefore, the assessment of $\mathrm{Na}^{+} / \mathrm{K}^{+}$-ATPase activity can be used as an index for oxidant-induced tissue injury and lipid peroxidation (Tuna et al. 2001). This can explain why liver and lymphoid tissue injuries were accompanied by a simultaneous increase in MDA and protein oxidation levels and a decrease in $\mathrm{Na}^{+} /$ $\mathrm{K}^{+}$-ATPase activity in the present study.

Recent studies have indicated reduced GSH level as one of the mechanisms involved in the pathogenesis of alcoholinduced tissue injury. Thiol agents, such as GSH, are involved in preventing the damage resulting from alcohol-induced ROS (Schlorff et al. 1999). Thus, the decrease in liver and lymphoid tissue GSH levels may be due to its consumption during the alcohol-induced oxidative stress. Specifically, the present study demonstrated an increased level of MDA and PO and a decreased level of GSH and $\mathrm{Na}^{+} / \mathrm{K}^{+}$-ATPase activity in the liver and lymphoid tissues of newborns for the first time. In accordance with the present results, previous reports also showed that the depletion of tissue GSH might permit LP and subsequent tissue damage (Cano et al. 2001).

Another noticeable finding in this study was that the GP and GR activities significantly decreased in G10 and G30 with respect to controls. The decrease could be attributed to diminishing GSH pool and regulation of redox balance and might generally be expected due to a possible increase in the formation of oxidized glutathione (GSSG) and the subsequent export of GSSG out of the cell (Aydin et al. 2007). This study also reported that both SOD and CAT activities were lower compared with those in the $\mathrm{C}$ group. The GP and CAT protected SOD against inactivation by $\mathrm{H}_{2} \mathrm{O}_{2}$. Reciprocally, SOD protected GP and CAT against superoxide anions (Vidyasagar et al. 2004).

The reduction in the activity of these enzymes and GSH levels and increased lipid peroxidation and protein oxidation could reflect the adverse effect of maternal alcohol on this finely balanced antioxidant system in the liver and lymphoid tissues of 10- and 30-day old newborns. The present study indicated that the fluid of the fetal compartment retained 
a peak alcohol concentration for a longer period of time due to the inability of the fetus to metabolize alcohol (Paintner et al. 2012), resulting in impairment in the oxidant/redox system in FAS, which was specific to the newborn liver and lymphoid tissues.

The activation of complement is required for the development of ethanol-induced tissue injury in mice (Cowell et al. 2003). However, the specific pathways by which ethanol exposure activates complement have not been identified. Ethanol feeding induces both complement activation and oxidative stress, even apoptosis (Higuchi et al. 1996). Furthermore, previous studies have shown the relationship between complement cascade and antioxidants (Lockwood and Gross 2005). Therefore, this study hypothesized that ethanol would activate the complement pathway, and C3 and C5 would contribute to ethanol-induced oxidative damage in lymphoid tissues. Recently, a close relationship was reported between $\mathrm{C} 3$ activation and excessive superoxide radicals. In this study, the natural free-radical scavenger, SOD, reduced ischemic brain injury and, simultaneously, the $\mathrm{C} 3$ level. These data implied that complement activation was directly related to oxidative stress (Yang et al. 2013). Moreover, endogenously generated C5 also exacerbated neuronal apoptosis under ischemic conditions (Pavlovski et al. 2012). In this study, the results showed that prenatal stress induced oxidative damage in lymphoid tissue of newborns (10- and 30-day old). Furthermore, plasma C3 and C5 levels significantly increased ( $p<0.01, p<0.001$; Figure 4$)$, implying that higher ROS levels showed higher C3 and C5 levels.

In conclusion, this study identified a causal relationship between ROS and C3 and C5 activation. The complement cascade was activated after ethanol induced tissue injury and had a deleterious role, and oxidative stress was closely associated with $\mathrm{C} 3$ and $\mathrm{C} 5$ activation. An antioxidant that can inhibit complement $\mathrm{C} 3$ activation and also possible C5 may offer a new strategy for therapeutic approaches in oxidative stress-related disorders such as alcoholic liver disease and stroke.

\section{References}

Abraham P, Wilfred G, Ramakrishna B (2002): Oxidative damage to the hepatocellular proteins after chronic ethanol intake in the rat. Clin. Chim. Acta 325, 117-125 https://doi.org/10.1016/S0009-8981(02)00279-6

Aebi H (1985): Catalase in vitro. Methods Enzymol. 105, 125-126

Augustyniak A, Skrzydlewska E (2010): The influence of L-carnitine suplementation on the antioxidative abilities of serum and the central nervous system of ethanol-induced rats. Metab. Brain Dis. 25, 381-389 https://doi.org/10.1007/s11011-010-9217-7

Aydın C, İnce E, Koparan S, Cangul T (2007): Protective effects of long term dietary restriction on swimming exercise-induced oxidative stres in liver, heart and kidney of rat. Cell Biochem. Func. 25, 129-137 https://doi.org/10.1002/cbf.1279

Beutler E, Duron O, Kelly B (1963): An improved method for the determination of blood glutathione. J. Lab. Clin. Med. 61, 822-826

Beutler E (1985): Red cell metabolism. In a manual of biochemical methods. pp. 72-131, 3th edition Grune\&Stratton, New York, NY

Brocardo PS, Gil Mohapel J, Christie BR (2011): The role of oxidative stress in fetal alcohol spectrum disorders. Brain Res. Rev. 67, 209-225 https://doi.org/10.1016/j.brainresrev.2011.02.001

Cano MJ, Murillo ML, Carreras O (2001): Protective effect of folic acid agains oxidative stress produced in 21 day postpartum rats by maternal ethanol chronic consumption during pregnancy and lactation period. Free Radic. Res. 34, 1-8 https://doi.org/10.1080/10715760100300011

Ceni E, Mello T, Galli A (2014): Pathogenesis of alcoholic liver disease: Role of oxidative metabolism. World J. Gastroenterol. 20, 17756-17772 https://doi.org/10.3748/wjg.v20.i47.17756

Cohen JI, Chen X, Nagyl LE (2011): Redox Signaling and the Innate Immune System in Alcoholic Liver Disease Antioxid. Redox Signal. 15, 523-534 https://doi.org/10.1089/ars.2010.3746

Collard CD, Lekowski R, Jordan JE, Agah A, Stahl GL (1999): Complement activation following oxidative stres. Mol. Immunol. 36, 941-948 https://doi.org/10.1016/S0161-5890(99)00116-9

Cowell RM, Plane JM, Silverstein FS (2003): Complement activation contributes to hypoxic-ischemic brain injury in neonatal rats. J. Neurosci. 23, 9459-9468 https://doi.org/10.1523/JNEUROSCI.23-28-09459.2003

Crabb DW, Matsumoto M, Chang D, You M (2004): Overview of the role of alcohol dehydrogenase and aldehyde dehydrogenase and their variants in the genesis of alcohol-related pathology. Proc. Nutr. Soc. 63, 49-63 https://doi.org/10.1079/PNS2003327

Davies GR, Simmonds NJ, Stevens TRJ, Grandison A, Blake DR, Rampton DS (1992): Mucosal reactive oxygen metabolite production in duodenal ulcer disease. Gut 33, 1467-1472 https://doi.org/10.1136/gut.33.11.1467

Deitrich R, Zimatkin S, Pronko S (2006): Oxidation of ethanol in the brain and its consequences. Alcohol Res. Health 29, 266-273

Dong J, Sulik KK, Chen SY (2010): The role of NOX enzymes in ethanol-induced oxidative stres and apoptosis in mouse embryos. Toxicol. Lett. 193, 94-100 https://doi.org/10.1016/j.toxlet.2009.12.012

Ducruet AF, Zacharia BE, Hickman ZL, Grobelny BT, Yeh ML, Sosunov SA, Jr. ESC (2009): The complement cascade as a therapeutic target in intracerebral hemorrhage. Exp. Neurol. 219, 398-403 https://doi.org/10.1016/j.expneurol.2009.07.018

Evans P, Lyras L, Halliwell B (1999): Measurement of protein carbonyls in human brain tissue. Methods Enzymol. 300, 145-156 https://doi.org/10.1016/S0076-6879(99)00122-6 
Ghebrehiwet B, Hosszu KH, Peerschke EI (2017): C1q as an autocrine and paracrine regulator of cellular functions. Mol. Immunol. 84, 26-33 https://doi.org/10.1016/j.molimm.2016.11.003

Greenberg DA (2003): Linking acquired neurodevelopmental disorders to defects in cell adhesion. Proc. Natl. Acad. Sci. USA 100, 8043-8044 https://doi.org/10.1073/pnas.1533226100

Guevara A, Gates H, Urbina B, French R (2018): Developmental ethanol exposure causes reduced feeding and reveals a critical role for neuropeptide $\mathrm{f}$ in survival. Front. Physiol. 9, 237 https://doi.org/10.3389/fphys.2018.00237

Haklar G, Yüksel M, Yalçın AS (1998): Chemiluminescence in the measurement of free radicals: theory and application on a tissue injury model. Marmara Med. J. 11, 56-60

Hatam L, Kayden HJ (1979): A high performance liquid chromatographic method for the determination of tocopherol in plasma and cellular elements of the blood. J. Lipid Res. 20, 639-645

Henderson GI, Chen JJ, Schenker S (1999): Ethanol, oxidative stress, reactive aldehydes and the fetus. Front. Biosci. 15, D541-550

Higuchi H, Kurose I, Kato S, Miura S, İschii H (1996): Ethanolinduced apoptosis and oxidative stress in hepatocytes. Alcohol Clin. Exp. Res. 20, 340A-346A https://doi.org/10.1111/j.1530-0277.1996.tb01804.x

Lockwood SF, Gross GJ (2005): Disodium disuccinate astaxanthin (Cardaxe): antioxidant and antiinflammatory cardioprotection. Cardiovasc. Drug Rev. 23, 199-216 https://doi.org/10.1111/j.1527-3466.2005.tb00166.x

Lowry OH, Rosebrough NJ, Farr AL, Randall RJ (1951): Protein measurement with the folin phenol reagent. J. Biol. Chem. 193, 265-275

Lundquist $F$ (1959): The determination of ethyl alcohol in blood and tissues. In: Methods of Biochemical Analysis 7, (Ed. D Glick), pp. 217, Interscience Publishers, Inc., New York, NY https://doi.org/10.1002/9780470110232.ch7

Mancinelli R (2014): Fetal alcohol spectrum disorders: can alcoholrelated oxidative stress concur to the prenatal damage? O. A. Alcohol. 2, 9

Marcondes FK, Bianchi, FJ, Tanno AP (2002): Determination of the estrous cycle phases of rats: some helpful considerations. Braz. J. Biol. 62, 609-614 https://doi.org/10.1590/S1519-69842002000400008

May PA, Gossage JP, Kalberg WO, Robinson LK, Buckley D, Manning M, Hoyme HE (2009): Prevalence and epide $\neg$ miologic characteristics of FASD from various research methods with an emphasis on recent in school studies. Dev. Disabil. Res. Rev. 15, 176-192 https://doi.org/10.1002/ddrr.68

Mevorach D, Mascarenhas JO, Gershov D, Elkon KB (1998): Complement dependent clearance of apoptotic cells by human macrophages. J. Exp. Med. 188, 2313-2320 https://doi.org/10.1084/jem.188.12.2313

Miller L, Shapiro AM, Cheng J, Wells PG (2018): The free radical spin trapping agent phenylbutylnitrone reduces fetal brain DNA oxidation and postnatal cognitive deficits caused by in utero exposure to anon-structurally teratogenic dose o fethanol: A role for oxidative stres. Free Radic. Biol. Med. 60, 223-232 https://doi.org/10.1016/j.freeradbiomed.2013.02.015
Mocco J, Mack WJ, Ducruet AF (2006): Complement component C3 mediates inflammatory injury following focal cerebral ischemia. Circ. Res. 99, 209-217 https://doi.org/10.1161/01.RES.0000232544.90675.42

Molina PE, Hoek JB, Nelson S, Guidot DM, Lang CH, Wands JR, Crawford JM (2003): Mechanisms of alcohol-induced tissue injury. Alcohol Clin. Exp. Res. 27, 563-575 https://doi.org/10.1097/01.ALC.0000057946.57330.F7

Ohara Y, Peterson TE, Harrison DG (1993): Hypercholesterolemia increases endothelial superoxide anion production. J. Clin. Invest. 91, 2546-2551 https://doi.org/10.1172/JCI116491

Ozerkan D, Ozsoy N, Cebesoy S (2014): Response of thymus lymphocytes to streptozotocin-induced diabetes and exogenous vitamin $\mathrm{C}$ administration in rats. Microscopy (Oxf) 63, 409-417 https://doi.org/10.1093/jmicro/dfu029

Paglia DE, Valentine WN (1967): Studies on the quantitative and qualitative characterization of erythrocyte glutathione peroxidase. J. Lab. Clin. Med.70, 158-169

Paintner A, Williams AD, Burd L (2012): Fetal alcohol spectrum disorders-implications for child neurology. Part 1: Prenatal exposure and dosimetry. J. Child. Neurol. 27, 258-263 https://doi.org/10.1177/0883073811428376

Pavlovski D, Thundyil J, Monk PN. Wetsel R.A, Taylor SM, Woodruff TM (2012): Generation of complement component C5a by ischemic neurons promotes neuronal apoptosis. FASEB J. 26, 3680-3690 https://doi.org/10.1096/fj.11-202382

Prabbu R, Balasubramanian KA (2003): Effect of oxidants on small intestinal brush border membranes and colonic apical membranes- a comparative study. Comp. Biochem. Physiol. Toxicol. Pharmacol. 134, 329-339 https://doi.org/10.1016/S1532-0456(02)00250-8

Pritchard MT, Mc Mullen MR, Stavitsky AB, Cohen, JI, Lin F, Medof ME, Nagy LE. (2007): Differential contributions of C3, C5, and decay-accelerating factor to ethanolinduced fatty liver in mice. Gastroenterology 132, 1117-1126 https://doi.org/10.1053/j.gastro.2007.01.053

Reading HW, İsbir T (1980): The role of cation activated ATPase in transmitter release from the art iris. Q.J. Exp. Physiol. 65, 105 https://doi.org/10.1113/expphysiol.1980.sp002495

Schlorff EC, Husain K, Somani SM (1999): Dose- and timedependent effects or ethanol on plasma antioxidant system in rat. Alcohol 17, 97-105 https://doi.org/10.1016/S0741-8329(98)00039-1

Shen H, French BA, Liu H, Tillman BC, French SW (2014): Increased activity of the complement system in the liver of patients with alcoholic hepatitis. Exp. Mol. Pathol. 97, 338-44 https://doi.org/10.1016/j.yexmp.2014.09.004

Shirpoor AR, Minassian S, Salami S, Ansari MHK, Yeghiazaryan M (2008): Alpha lipoic acid decreases DNA damage and oxidative stress induced by alcohol in the developing hippocampus and cerebellum of rat. Cell Physiol. Biochem. 22, 769-776 https://doi.org/10.1159/000185560

Singh RP, Padmavathi B, Rao R (2000): Modulatory influence of Adhatoda vesicaleaf extract on the enzymes of xenobiotic 
metabolism, antioxidant status and lipid peroxidation in mice. Mol. Cell Biochem. 213, 99-109

https://doi.org/10.1023/A:1007182913931

Tuna M, Polat S, Erman T, Gocer AI, Tuna N, Tamer L, Kaya M, Cetinalp E (2001): Effect of anti rat interleukin-6 antibody after spinal cord injury in the rat: inducible nitric oxide synthase expression sodium and potassium activated, magnesiumdependent adenosin 5 phosphatase and superoxide dismutase activation, and ultra sutructural changes. J. Neurosurg. 95, 64-73

https://doi.org/10.3171/spi.2001.95.1.0064

Terasaki LS, Schwarz JM (2016): Effects of moderate prenatal alcohol exposure during early gestation in rats on inflammation across the maternal-fetal-immune interface and later-life immune function in the offspring. J. Neuroimmune Pharmacol. 11, 680-692

https://doi.org/10.1007/s11481-016-9691-8
Vidyasagar J, Karunakar N, Riddy MS, Rajnayarana R (2004): Oxidative stres and antioxidant status in acute organophosphorus insecticide poising. Indian J. Pharmacol. 36, 76-79

Winterbourn CC, Hawkins RE, Brain M, Carrel W (1975): The estimation of red cell superoxide dismutase activity. J. Lab. Clin. Med. 55, 337-341

Wu D, Cederbaum AI (2003): Alcohol, oxidative stress, and free radical damage. Alcohol Res. Health. 27, 277-284

Yang J, Ahn H, Chang M, Narasimhan P (2013): Complement component 3 inhibition by an antioxidant is neuroprotective after cerebral ischemia and reperfusion in mice. J. Neurochem. 124, 523-535

https://doi.org/10.1111/jnc.12111

Received: February 26, 2018

Final version accepted: May 22, 2018

First published online: January 18, 2019 